\title{
Comparative Performance of Sugarcane Bagasse and Black Polyethylene as Mulch for Squash (Cucurbita pepo L.) Production
}

\author{
Charles L. Webber III ${ }^{1}$, Paul M. White Jr. ${ }^{1}$, Douglas J. Spaunhorst ${ }^{1}$ \& Eric C. Petrie ${ }^{1}$ \\ ${ }^{1}$ USDA, Agriculture Research Service, Sugarcane Research Unit, Houma, LA, USA \\ Correspondence: Charles L. Webber III, USDA, Agriculture Research Service, Sugarcane Research Unit, Houma, \\ LA 70360, USA. E-mail: chuck.webber@ars.usda.gov
}

\author{
Received: July 18, $2017 \quad$ Accepted: August 29, $2017 \quad$ Online Published: October 15, 2017 \\ doi:10.5539/jas.v9n11p1 URL: https://doi.org/10.5539/jas.v9n11p1
}

\begin{abstract}
Louisiana processed 11.7 million $\mathrm{mt}$ of sugarcane in 2016, producing 1.47 million $\mathrm{mt}$ of raw sugar and an estimated 3.5 million $\mathrm{mt}$ of bagasse. Sugarcane bagasse is the fibrous material remaining after removing the sucrose, water, and other impurities (filter mud) from the millable sugarcane. Typically, Louisiana sugarcane mills burn a portion of the bagasse to heat boilers to steam power the mill for grinding and sugar processing. The balance of the bagasse is stored at the sugar mill where it accumulates in immense piles. Research was conducted in 2015 and 2016 to investigate the use of sugarcane bagasse as a natural mulch for vegetable production. The field experiment compared sugarcane bagasse mulch, black plastic mulch, and no mulch (control) for suitable mulching treatments for squash (Cucurbita pepo L.) production. The black plastic mulch produced significantly greater marketable fruits/plant, fruit number, and total yield $(\mathrm{kg} / \mathrm{ha})$ across years compared to the sugarcane bagasse mulch. The sugarcane bagasse mulch and the no mulch control were not significantly different for these same parameters. Black plastic also produced heaver fruit ( $\mathrm{g} /$ fruit) than the sugarcane bagasse mulch and the control in 2015. The black plastic mulch produced greater yields due to the greater cumulative growing degree days (CGDD) received compared to the sugarcane bagasse mulch and no mulch control. The sugarcane bagasse mulch tended to mitigate temperature extremes by serving as a soil insulator. Future research should investigate the potential deleterious impact, if any, of the sugarcane bagasse on soil microbes, $\mathrm{C} / \mathrm{N}$ ratio, soil $\mathrm{pH}$, and allelopathy, which might adversely influence cucurbit growth.
\end{abstract}

Keywords: accumulative growing degree days, agricultural by-products, bagasse, certified organic, natural mulches, squash, sugarcane

\section{Introduction}

\subsection{Sugarcane Bagasse Uses}

In 2016, Louisiana sugarcane farmers harvested 11.7 million $\mathrm{mt}$ millable sugarcane from 163,000 ha, producing 1.47 million $\mathrm{mt}$ of raw sugar and an estimated 3.5 million mt of bagasse (American Sugar Cane League, 2017). Global sugar production in 2016 was over 171 million mt of raw sugar, which resulted in over 300 million mt of bagasse (United States Department of Agriculture, 2017). Bagasse is the fibrous by-products produced when removing the sugar, water, and other superfluous materials from the millable sugarcane. On the dry weight basis, bagasse is primarily composed of cellulose (40-50\%), hemicellulose (30-35\%), and lignin (20-30\%) (Amin, 2011; Cardona et al., 2010; A. R. F. Drummond \& I. W. Drummond, 1996; Martin et al., 2007; Pandey et al., 2000; Sales \& Lima, 2010). As a plentiful by-product, sugarcane bagasse has been successfully used as a fiber source for paper and construction board production (Amin, 2011; Xin et al., 2002). Nigam (1990) and Pandey et al. (2000) investigated its use as a cattle feed, while others have used in as anendment to potting media (Jhurree-Dussoruth et al., 2011; Trochoulias et al., 1990). There is also current and past interest in using the bagasse a source for value added products (i.e. pigments, enzymes, amino acids, and drugs) (Pandey et al., 2000). The most common use for the bagasse by the sugarcane industry is as an energy source (thermal conversion and ethanol) (Badger, 2002; Kilicaslan et al., 1999; Martin et al., 2007; Peng et al., 2009; Sun \& Cheng, 2002).

Due to the abundant surplus supply of bagasse at Louisiana sugarcane sugar mills, research was initiated to determine additional uses for sugarcane bagasse. The long frost-free growing season, 230-290 days a year, in southern Louisiana that favors sugarcane production also provides an ideal environment for vegetable 
production. Plastic and organic mulches are used in vegetable production to enhance soil temperatures, retain soil moisture, prevent soil erosion, and decrease pest infestations. The objective of the research was to determine the feasibility of using sugarcane bagasse as planting mulch for field produced vegetables.

\section{Material and Methods}

\subsection{Experimental Design}

The field experiment compared sugarcane bagasse mulch, black plastic mulch, and no mulch (control) for suitable mulching treatments for squash (Cucurbita pepo L.) production. The experiment was conducted in the spring of 2015 and 2016 at the USDA, ARS, Sugarcane Research Center, Houma, LA, USA on a Cancienne silt loam and Cancienne silty clay loam soil, 0 to $1 \%$ slope. The experiment was laid out as a randomized complete block design with 3 mulching treatments, 4 replications, 3 rows/plot (5.3 m wide), $1.8 \mathrm{~m}$ row spacing, and $7.6 \mathrm{~m}$ plot lengths. Prior to planting each year the soil was fertilized with $65 \mathrm{~kg} / \mathrm{ha}$ of N-P-K (April 6, 2015 and April 5, 2016), tilled, and made into $91 \mathrm{~cm}$ wide $18-\mathrm{cm}$ high raised beds on $1.8 \mathrm{~m}$ row centers. A $13 \mathrm{~mm}$ irrigation drip line with inline emitters every $30.5 \mathrm{~cm}$ was placed on the top of each raised bed just off of the center line for the entire study. The sugarcane bagasse was applied to the top of the raised bed to a depth of $7.6 \mathrm{~cm}(88 \mathrm{mt} / \mathrm{ha})$. The sugarcane bagasse mulch was obtained from the Lafourche Sugar Corp. sugar mill, Thibodaux, LA. The $1.2 \mathrm{~m}$ wide black 1 mil plastic mulch was placed on top of the raised beds and secured on each side and both ends by soil between the raised beds (April 9, 2015 and April 6, 2016). The control plots, which had no mulch, received a broadcast application $(187 \mathrm{~L} / \mathrm{ha})$ of pendemethalin $(1.7 \mathrm{~kg}$ ai $/ \mathrm{ha})$ and metolachlor $(1.7 \mathrm{~kg}$ ai/ha), XR8002VS nozzle. Following the application of the mulches, yellow squash variety 'Enterprise' seeds were direct-seeded $45 \mathrm{~cm}$ apart the length of each plot on May 4, 2015 and May 5, 2016. Squash plant stands were thinned to a consistent plant population of 12,300 plants/ha (45 cm between plants within rows) (Figure 1).

\subsection{Temperature and Cumulative Growing Degree Day Calculations}

Weather data were obtained from a nearby on-farm weather station that recorded environmental variables every 10 seconds and averaged every minute to provide daily maximum and minimum temperatures (Ardoyne Farm, USDA, ARS, Sugarcane Research Unit, Shriever, LA, USA). Although, ambient air temperatures are typically used to determine degree days, it is understood that the soil temperatures might be different (Yousef et al., 2013), therefore, data loggers were used in 2015 to monitor soil temperatures at $2.54 \mathrm{~cm}$. Two soil temperature data loggers (HOBO ${ }^{\circledR}$ Pendant Temperature Data Logger UA-001-08, Onset Computer Corporation, Pocasset, MA, USA) were place within each plot at a depth $2.54 \mathrm{~cm}$ (seeding depth) and recorded temperatures every 10 minutes.

The following formula was used to estimate cumulative growing degree days (GDD); CGDD $=\left[\left(\mathrm{T}_{\max }+\mathrm{T}_{\min }\right) / 2\right]-$ $\mathrm{T}_{\text {base }}$ GDD were calculated using a base temperature $\left(\mathrm{T}_{\text {base }}\right)$ of $8{ }^{\circ} \mathrm{C}$ for squash (Coolong, 2017; Maynard \& Hochmuth, 2007; NeSmith \& Hoogenboom, 1994; Yousef et al., 2013) and a daily maximum temperature $\left(\mathrm{T}_{\max }\right)$ of $32{ }^{\circ} \mathrm{C}$ (Coolong, 2017; NeSmith, 1997; NeSmith \& Hoogenboom, 1994; Yousef et al., 2013). The daily minimum temperature $\left(\mathrm{T}_{\min }\right)$ was used for all calculations.

Soil moisture was maintained during the experiment by rainfall supplemented with drip irrigation. Squash fruit was harvested three times a week for a total of 19 harvests, June 3 to July 15, 2015 and June 6 to July 20, 2016 from the center row of each 3 row plot. The fruit was separated into marketable (unblemished, 13 to $20 \mathrm{~cm}$ long) and unmarketable (blemished) fruit, counted, and weighed. All data were subjected to ANOVA and mean separation using LSD with $\mathrm{P}=0.05$ (SAS Inc., SAS, Ver. 9.0, Cary, NC). 

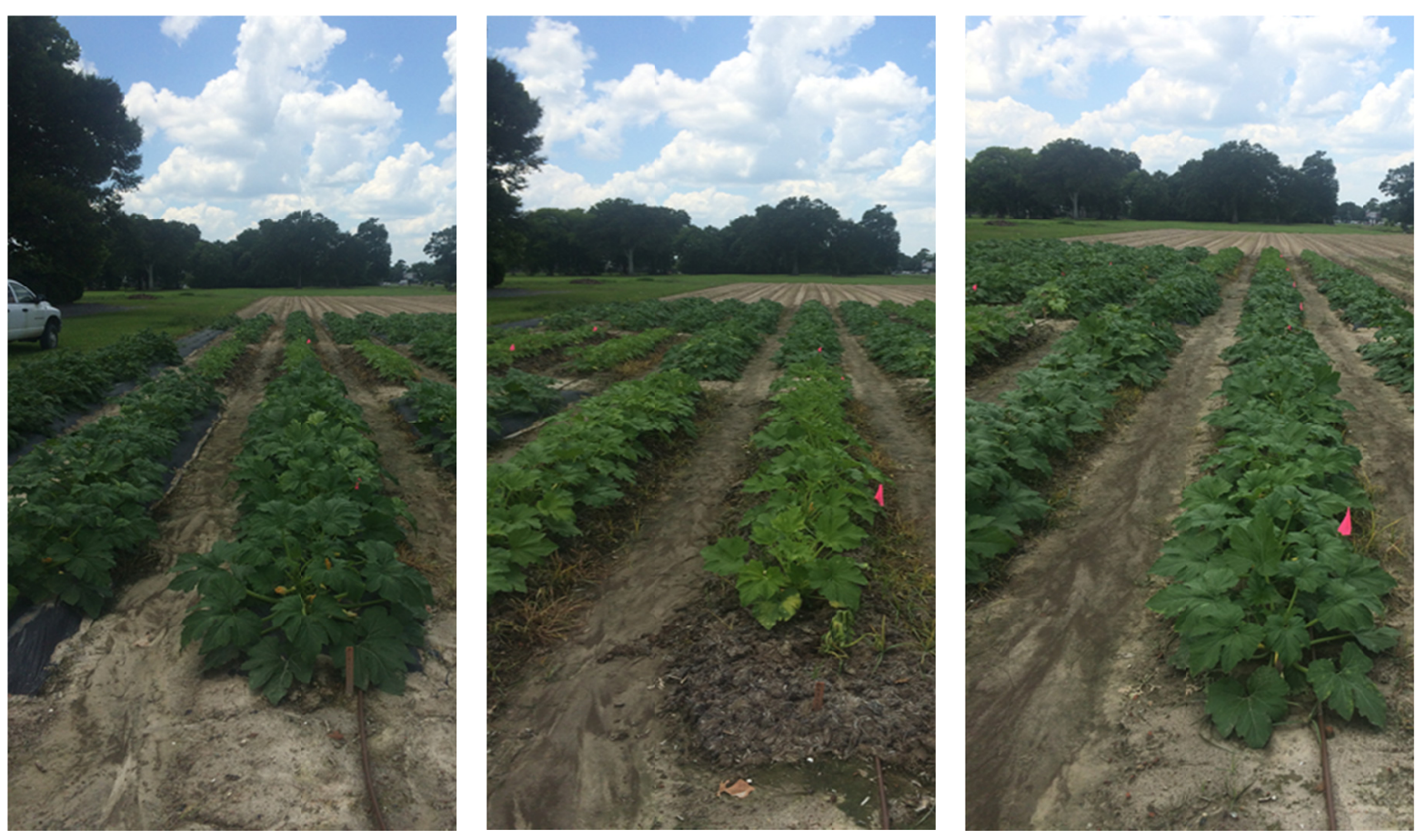

Figure 1. Squash plants growing on black plastic mulch, sugarcane bagasse mulch, and without mulch (bare soil), left, middle, and right, respectively

\section{Results and Discussion}

\subsection{Statistical Analysis}

There were no significant year by treatment interactions for the squash production parameters of marketable and non-marketable average plant production (fruit/plant), fruit number (fruit/ha), and yield ( $\mathrm{kg} / \mathrm{ha}$ ), therefore, these parameters will be discussed across treatment and years (Tables 3-6). The statistical analysis did detect a significant year by treatment interaction for marketable fruit weight ( $g /$ fruit), therefore, fruit weight will be discussed by treatment for each year, 2015 and 2016 (Table 7).

\subsection{Temperature Data and Cumulative Growing Degrees Days}

Minimum, maximum, and average air temperatures were very similar across years (Table 1). The CGDD was slightly higher in 2016 compared to 2015, 63 CGDD, a 4.5\% difference, but it must be noted that 2016 had 4 additional days, $77 \mathrm{~d}$ compared to $73 \mathrm{~d}$, to accumulate heat units compared to 2015 (Table 1). When averaged over the entire growing periods, planting to final harvest, the daily average degree days (DADD) for the two years were 19.1 and 18.9, 2015 and 2016, respectively (Table 1).

Table 1. Average minimum, maximum, average air temperatures, cumulative growing degree days CGDD, and the daily average degree days (DADD) from planting to final harvest, 73 days and 77 days, for 2015 and 2016, respectively

\begin{tabular}{llllll}
\hline Year & Minimum $^{\mathrm{Z}}$ & Maximum $^{\mathrm{Y}}$ & Average $^{\mathrm{X}}$ & CGDD $^{\mathrm{W}}$ & DADD $^{\mathrm{V}}$ \\
\hline & $\left({ }^{\circ} \mathrm{C}\right)$ & $\left({ }^{\circ} \mathrm{C}\right)$ & $\left({ }^{\circ} \mathrm{C}\right)$ & & \\
$2015^{\mathrm{U}}$ & 21.7 & 31.4 & 26.1 & 1,394 & 19.1 \\
$2016^{\mathrm{T}}$ & 21.5 & 31.6 & 26.0 & 1,457 & 18.9 \\
\hline
\end{tabular}

Note. ${ }^{\mathrm{Z}}$ Daily average minimum air temperatures from planting to the final harvest; ${ }^{\mathrm{Y}}$ Daily average maximum air temperatures from planting to the final harvest; ${ }^{\mathrm{x}}$ Daily average air temperatures from planting to the final harvest; ${ }^{\mathrm{W}}$ Cumulative degree days, $\mathrm{CGDD}=\left[\left(\mathrm{T}_{\max }+\mathrm{T}_{\min }\right) / 2\right]-\mathrm{T}_{\text {base }}$, where $\mathrm{T}_{\text {base }}$ and $\mathrm{T}_{\min }=8{ }^{\circ} \mathrm{C}, \mathrm{T}_{\max }$ limited to $32{ }^{\circ} \mathrm{C}$; ${ }^{\mathrm{V}}$ Cumulative degree days average across days from planting to final harvest for each year; ${ }^{\mathrm{U}} 2015$ : Planting to final harvest $=73$ days; ${ }^{\mathrm{T}} 2016$ : Planting to final harvest $=77$ days. 
Although the 2015 and 2016 minimum, maximum, and average air temperatures were equivalent across years, which resulted in similar CGDD and DADD values (Table 1), the mulching treatments significantly impacted the minimum, maximum, and average soil temperatures at $2.54 \mathrm{~cm}$ depth (Table 2). The differences in soil temperatures, therefore, significantly influenced CGDD and DADD among mulching treatments (Table 2). Black plastic produced higher minimum soil temperatures than the control (no mulch), but was not different than the sugarcane bagasse (Table 2). In all soil related parameters (maximum and average soil temperatures, CGDD and DADD) the black plastic was significantly greater than either the sugarcane mulch or the no mulch control (Table 2). The no mulch control was not significantly different than the sugarcane bagasse for average soil temperature, which might be expected due to the differences between the treatments for minimum and maximum soil temperatures, where the control had numerically slightly lower minimum temperatures, but not significantly different, and significantly greater maximum temperatures compared to the sugarcane bagasse mulch (Table 2).

It is interesting to note the differences between temperature parameters for the 2015 air temperatures and the soil temperatures (Tables 1 and 2). Numerically, the soil temperatures for all mulching treatments were greater than the 2015 air temperatures, while only marginally greater for maximum temperatures for black plastic $\left(33.5^{\circ} \mathrm{C}\right.$ vs. $\left.31.4^{\circ} \mathrm{C}\right)$ and the control $\left(32.5^{\circ} \mathrm{C}\right.$ vs. $\left.31.4^{\circ} \mathrm{C}\right)($ Tables 1 and 2$)$. There were 29 days $(40 \%)$ and 39 days $(51 \%)$ in 2015 and 2016, respectively, that exceeded $\mathrm{T}_{\max }\left(32^{\circ} \mathrm{C}\right)$ for air temperatures, compared to 45 days $(61 \%), 11$ days $(15 \%)$, and 34 days $(47 \%)$ for 2015 where the soil temperatures exceeded $\mathrm{T}_{\max }\left(32{ }^{\circ} \mathrm{C}\right)$ for the black plastic, sugarcane bagasse, and the control, respectively (data not shown). The number of days exceeding $\mathrm{T}_{\max }$ also corresponded to the maximum soil temperatures for the mulches in 2015 (Table 2). Yet, the cumulative impact resulted in a large difference between the soil CGDD compared to the air temperature CGDD (Tables 1 and 2). Although, soil temperatures were not collected in 2016, it would be reasonable to expect a similar impact on soil parameters in 2016 due to the almost identical air temperatures parameters between years (Table 1).

Table 2. Average minimum, maximum, average soil temperatures at $2.54 \mathrm{~cm}$, cumulative growing degree days CGDD, and the daily average degree days (DADD) from planting to final harvest, 73 days, for 2015

\begin{tabular}{llllll}
\hline Mulch Treatment & Minimum $^{\mathrm{Z}}$ & Maximum $^{\mathrm{Y}}$ & Average $^{\mathrm{X}}$ & CGDD $^{\mathrm{Z}}$ & DADD $^{\mathrm{Y}}$ \\
\hline & $\left({ }^{\circ} \mathrm{C}\right)$ & $\left({ }^{\circ} \mathrm{C}\right)$ & $\left({ }^{\circ} \mathrm{C}\right)$ & & \\
Black Plastic & $26.5 \mathrm{a}^{\mathrm{T}}$ & $33.5 \mathrm{a}$ & $29.4 \mathrm{a}$ & $2,748 \mathrm{a}$ & $37.6 \mathrm{a}$ \\
Sugarcane Bagasse & $26.0 \mathrm{ab}$ & $30.9 \mathrm{c}$ & $27.7 \mathrm{~b}$ & $2,571 \mathrm{c}$ & $35.2 \mathrm{c}$ \\
Control (No Mulch) & $25.2 \mathrm{~b}$ & $32.5 \mathrm{~b}$ & $27.9 \mathrm{~b}$ & $2,666 \mathrm{~b}$ & $36.5 \mathrm{~b}$
\end{tabular}

Note. ${ }^{\mathrm{Z}}$ Daily average minimum soil temperatures at $2.54 \mathrm{~cm}$ from planning to the final harvest; ${ }^{\mathrm{Y}}$ Daily average maximum soil temperatures at $2.54 \mathrm{~cm}$ from planning to the final harvest; ${ }^{{ }}$Daily average soil temperatures from planting to the final harvest; ${ }^{\mathrm{Z}}$ Cumulative degree days, CGDD $=\left[\left(\mathrm{T}_{\max }+\mathrm{T}_{\min }\right) / 2\right]-\mathrm{T}_{\text {base }}$, where $\mathrm{T}_{\text {base }}$ and $\mathrm{T}_{\min }=$ $8{ }^{\circ} \mathrm{C}$, $\mathrm{T}_{\max }$ limited to $32{ }^{\circ} \mathrm{C}$; ${ }^{\mathrm{Y}}$ Cumulative degree days average across days from planting to final harvest for 2015; ${ }^{\mathrm{V}} 2015$ : Planting to final harvest $=73$ days; ${ }^{\mathrm{U}} 2016$ : Planting to final harvest $=77$ days; ${ }^{\mathrm{T}}$ Means in a column followed by the same lower case letter are not significantly different at $\mathrm{P} \leq 0.05$, ANOVA.

\subsection{Marketable Plant Production (fruit/plant), Fruit Number (fruit/ha), and Yield (kg/ha) Averaged across 2015 and 2016}

Marketable fruits per plant, fruit number, and yield weight were significantly greater for the black plastic mulch compared to the sugarcane bagasse mulch averaged across years, and greater than the control for fruits per plant and fruit number (Table 3). The control (no mulch) was not significantly different from the sugarcane mulch across these parameters (Table 3 ).

Table 3. Impact of the mulch type (black plastic, sugarcane bagasse, and control (no mulch) on marketable yellow squash production in Louisiana averaged across years, 2015 and 2016

\begin{tabular}{llll}
\hline \multirow{2}{*}{ Mulch Treatment } & \multicolumn{2}{c}{ Fruit Parameters } & \multicolumn{1}{l}{ Yield } \\
\cline { 2 - 3 } & (fruit/plant) & (fruit/ha) & $39,621 \mathrm{a}$ \\
\hline Black Plastic & $15.95 \mathrm{a}^{\mathrm{z}}$ & $196,195 \mathrm{a}$ & $28,738 \mathrm{~b}$ \\
Sugarcane Bagasse & $12.23 \mathrm{~b}$ & $150,375 \mathrm{~b}$ & $31,613 \mathrm{ab}$ \\
Control (No Mulch) & $12.84 \mathrm{~b}$ & $150,375 \mathrm{~b}$ & \\
\hline
\end{tabular}

Note. ${ }^{\mathrm{Z}}$ Means in a column followed by the same lower case letter are not significantly different at $\mathrm{P} \leq 0.05$, ANOVA. 
There were significant differences between years, 2015 and 2016, for marketable fruits per plant and fruit number, with 2016 producing more fruit per plant and total fruit number than in 2015, but with greater, but not significantly different total yield ( $\mathrm{kg} / \mathrm{ha})$ (Table 4$)$.

Table 4. Impact of growing season, 2015 and 2016, averaged across the three mulching treatments (plastic, bagasse, and control) on marketable yellow squash production in Louisiana

\begin{tabular}{lllll}
\hline \multirow{2}{*}{ Year } & \multicolumn{2}{c}{ Fruit Parameters } & & Yield \\
\cline { 2 - 3 } & (fruit/plant) & (fruit/ha) & & (kg/ha) \\
\hline 2015 & $11.825 \mathrm{~b}^{\mathrm{z}}$ & $145,455 \mathrm{~b}$ & $30,315 \mathrm{a}$ \\
2016 & $15.517 \mathrm{a}$ & $190,865 \mathrm{a}$ & $36,332 \mathrm{a}$ \\
\hline
\end{tabular}

Note. ${ }^{\mathrm{Z}}$ Means in a column followed by the same lower case letter are not significantly different at $\mathrm{P} \leq 0.05$, ANOVA.

\subsection{Non-Marketable Plant Production (fruit/plant), Fruit Number (fruit/ha), and Yield (kg/ha) Averaged across 2015 and 2016}

Unlike the marketable fruit, there were no significant differences among the mulching treatments for fruit per plant, fruit number, or fruit yield (Table 5). Although numerically there was a tendency for greater fruit loss, non-marketable fruit, for the black plastic, the values were not significantly greater (Table 5) and were likely due to the greater overall fruit production by the black plastic mulch (Table 3).

Table 5. Impact of the mulch type (black plastic, sugarcane bagasse, and no mulch/control) on non-marketable yellow squash production in Louisiana averaged across years, 2015 and 2016

\begin{tabular}{llll}
\hline \multirow{2}{*}{ Mulch Treatment } & \multicolumn{2}{c}{ Fruit Parameters } & \multicolumn{1}{l}{ Yield } \\
\cline { 2 - 3 } & (fruit/plant) & (fruit/ha) & $1,400 \mathrm{a}$ \\
\hline Black Plastic & $0.40 \mathrm{a}^{\mathrm{z}}$ & $4,920 \mathrm{a}$ & $690 \mathrm{a}$ \\
Sugarcane Bagasse & $0.26 \mathrm{a}$ & $3,229 \mathrm{a}$ & $639 \mathrm{a}$ \\
Control (No Mulch) & $0.31 \mathrm{a}$ & $3,844 \mathrm{a}$ & \\
\hline
\end{tabular}

Note. ${ }^{\mathrm{Z}}$ Means in a column followed by the same lower case letter are not significantly different at $\mathrm{P} \leq 0.05$, ANOVA.

Non-marketable fruit production (fruit/plant, fruit/ha, and $\mathrm{kg} / \mathrm{ha}$ ) followed the same trend as the marketable fruit data (Table 6). Non-marketable fruit losses for fruit/plant and fruit/ha were greater in 2016 compared to 2015, while the total yield $(\mathrm{kg} / \mathrm{ha})$ was not significantly different. Non-marketable fruit losses in 2015 averaged near $1.5 \%$ of the marketable yields, while in 2016 the non-marketable fruit losses were at least $3 \%$ (calculated values), but still within acceptable ranges.

Table 6. Impact of growing season, 2015 and 2016, averaged across the three mulching treatments (plastic, bagasse, and control) on non-marketable yellow squash production in Louisiana

\begin{tabular}{|c|c|c|c|}
\hline \multirow{2}{*}{ Year } & \multicolumn{2}{|c|}{ Fruit Parameters } & \multirow{2}{*}{$\begin{array}{l}\text { Yield } \\
\text { (kg/ha) }\end{array}$} \\
\hline & (fruit/plant) & (fruit/ha) & \\
\hline 2015 & $0.16 b^{z}$ & $1,948 \mathrm{~b}$ & $452 \mathrm{a}$ \\
\hline 2016 & $0.49 \mathrm{a}$ & $6,048 \mathrm{a}$ & $1,367 \mathrm{a}$ \\
\hline
\end{tabular}

Note. ${ }^{\mathrm{Z}}$ Means in a column followed by the same lower case letter are not significantly different at $\mathrm{P} \leq 0.05$, ANOVA.

\subsection{Marketable and Non-Marketable Fruit Weight (g/fruit) by Mulching Treatment for 2015 and 2016}

Statistical analysis detected a significant year by treatment interaction $(\mathrm{P} \leq 0.05)$ for marketable fruit weight ( $\mathrm{g} /$ fruit), but not for non-marketable fruit weight, although marketable and non-marketable fruit weight did vary between years among the mulching treatments (Table 7). In 2016 there was not a significant difference among 
mulching treatments for both marketable and non-marketable fruit. In 2015 the black plastic mulch produced heavier marketable fruits than the sugarcane bagasse mulch, but was not significantly different than the control. The non-marketable fruit for the black plastic were heavier than those for the sugarcane bagasse mulch and the control (Table 7).

Table 7. Impact of the mulch type (black plastic, sugarcane bagasse, and control/mulch) on marketable and non-marketable yellow squash fruit weight (g/fruit) by year, 2015 and 2016

\begin{tabular}{lll}
\hline Mulch Treatment & Marketable $^{\mathrm{z}}$ & Non-marketable $^{\mathrm{y}}$ \\
\hline 2015 & $(\mathrm{~g} /$ fruit $)$ & $(\mathrm{g} /$ fruit $)$ \\
Black Plastic & $220 \mathrm{a}^{\mathrm{x}}$ & $295 \mathrm{a}$ \\
Sugarcane Bagasse & $184 \mathrm{~b}$ & $102 \mathrm{~b}$ \\
Control (No Mulch) & $210 \mathrm{ab}$ & $101 \mathrm{~b}$ \\
\hline 2016 & $186 \mathrm{a}^{\mathrm{x}}$ & $251 \mathrm{a}$ \\
Black Plastic & $194 \mathrm{a}$ & $183 \mathrm{a}$ \\
Sugarcane Bagasse & $190 \mathrm{a}$ & $170 \mathrm{a}$ \\
Control (No Mulch) & & \\
\hline
\end{tabular}

Note. ${ }^{\mathrm{z}}$ Significant year by treatment intereaction at $\mathrm{P} \leq 0.05$ for marketable fruit weight (g/fruit). ${ }^{\mathrm{y}}$ No significant year by treatment interaction at $\mathrm{P} \leq 0.05$ for non-marketable fruit weight $(\mathrm{g} / \mathrm{fruit}) .{ }^{\mathrm{x}} \mathrm{Means}$ in a column within years followed by the same lower case letter are not significantly different at $\mathrm{P} \leq 0.05$, ANOVA.

\subsection{Pest Control and General Plant Appearances}

Weeds, insects, and diseases were not an issue in the experiment. The weeds were controlled by either the preemergence herbicides, mulches, or by hand-weeding, and no damaging infestation of insects or diseases were observed. In general, the squash plants in the black plastic treatment appeared more robust, followed by the no mulch control, and lastly by sugarcane bagasse mulch. During both years the sugarcane bagasse mulched plants were a lighter green in color, tending to a yellow tinge (Figure 1).

\section{Conclusions}

The black plastic mulch produced significantly greater marketable fruit/plant, fruit number, and total yield $(\mathrm{kg} / \mathrm{ha})$ across years compared to the sugarcane bagasse mulch (Table 3$)$. The sugarcane bagasse mulch and the no mulch control were not significantly different for these same parameters (Table 3). Black plastic also produced heaver fruit (g/fruit) than the sugarcane bagasse mulch or the no mulch control in 2015 (Table 7). The greater yields produced by the black plastic mulch were likely larger due to the greater CGDD and DADD compared to the sugarcane bagasse mulch and no mulch control, which resulted from greater absorption and retention of heat units during the growing season (Table 2) (NeSmith, 1997; NeSmith \& Hoogenboom, 1994). The sugarcane bagasse mulch tended to mitigate temperature extremes by serving as a soil insulator (Table 2).

In addition to the direct impact of cumulative growing degree days, other factors may have attributed to the yield differences between the black plastic mulch and the sugarcane bagasse mulch. These factors include the influence of carbon to nitrogen ratio $(\mathrm{C} / \mathrm{N}), \mathrm{pH}$, and allelopathy. The tendency of the sugarcane bagasse mulch squash plants to become yellowish during the growing season may be a result the high $\mathrm{C}: \mathrm{N}$ ratio resulted from the direct contact of the sugarcane bagasse and the soil surface. Bagasse has high percentages cellulose (40-50\%), hemicellulose (30-35\%) and lignin (20-30\%) (Amin, 2011; Cardona et al., 2010; A. R. F. Drummond \& I. W. Drummond, 1996; Martin et al., 2007; Pandey et al., 2000; Sales \& Lima, 2010), resulting in a reported 100:1 C/N ratio (Meunchang et al., 2005). High $\mathrm{C} / \mathrm{N}$ ratios such as 100, can adversely impact the microbial activity at the soil and interface, resulting in binding up of more nitrogen, which becomes less available to the crop plant (Meunchang et al., 2005). The less than optimum nitrogen availability may have caused the sugarcane bagasse mulched plants to become yellowish and therefore less productive.

The low sugarcane bagasse $\mathrm{pH}$ (4.1) may have adversely impacted the soil's microbial populations decreasing nitrogen availability or plant nutrient uptake (Meunchang et al., 2005), therefore, adversely affecting squash growth and production, which requires an optimum $\mathrm{pH}$ of 6.0 to 6.5 (Kemble et al., 2005).

Lastly, the leaching or the microbial breakdown of the bagasse may have had an allelopathic (toxic) impact on the squash plants (Facelli \& Pickett, 1991; Rice, 1984; Rodrigues et al., 2001). Numerous researches have 
documented the presence of allelopathic chemicals in sugarcane leaves (De Carvalho et al., 2005; Singh et al., 2003; Viator et al., 2006) and straw (Sampietro et al., 2007; Sampietro et al., 2005; Sampietro \& Vattuone, 2006a, 2006b; Wang et al., 1967). Rodrigues et al. (2001) documented that the breakdown of sugarcane bagasse lignocellulosic material produced toxic compounds that inhibit cellular growth.

Although the additional heat units were the greatest contributing growth and production factor for the squash plants produced with the black plastic, further research should involve a closer examination of the potential impact of the sugarcane bagasse on soil microbes, $\mathrm{C} / \mathrm{N}$ ratio, soil $\mathrm{pH}$, and allelopathy. An economic analysis of the costs and benefits of the use of black plastic and sugarcane bagasse would also provide valuable information to a producer.

\section{Acknowledgements}

The work would have been impossible without the technical support of USDA, Agricultural Research Service technicians Derek Landrum, Christopher Adams, Norris Matherne, and Frank Randell for their technical support.

\section{Trade Names or Commercial Products}

Mention of trade names or commercial products in this publication is solely for the purpose of providing specific information and does not imply recommendation or endorsement by the U.S. Department of Agriculture.

\section{EEO/Non-Discrimination Statement}

The U.S. Department of Agriculture (USDA) prohibits discrimination in all its programs and activities on the basis of race, color, national origin, age, disability, and where applicable, sex, marital status, familial status, parental status, religion, sexual orientation, genetic information, political beliefs, reprisal, or because all or part of an individual's income is derived from any public assistance program. (Not all prohibited bases apply to all programs.) Persons with disabilities who require alternative means for communication of program information (Braille, large print, audiotape, etc.) should contact USDA's TARGET Center at (202) 720-2600 (voice and TDD). To file a complaint of discrimination, write to USDA, Director, Office of Civil Rights, 1400 Independence Avenue, S.W., Washington, D.C. 20250-9410, or call (800) 795-3272 (voice) or (202) 720-6382 (TDD). USDA is an equal opportunity provider and employer.

\section{References}

American Sugar Cane League. (2017). The Louisiana sugarcane industry production data 1975-2016. Retrieved August 14, 2017, from http://amscl.org/Images/Interior/sugar\%20industry\%20pamphlet/industryproduction data1975-2016.pdf

Amin, N. (2011). Use of bagasse ash in concrete and its impact on the strength and chloride resistivity. $J$. Mater. Civ. Eng., 23(5), 717-720. https://doi.org/10.1061/(ASCE)MT.1943-5533.0000227

Badger, P. C. (2002). Ethanol from cellulose: A general review. In J. Janick \& A. Whipkey (Eds.), Trends in new crops and new uses (pp. 17-21). ASHS Press, Alexandria, VA.

Cardona, C. A., Quintero, J. A., \& Paz, I. C. (2010). Production of bioethanol from sugarcane bagasse: Status and perspectives. Bioresource Techn., 101(13), 4754-4766. https://doi.org/10.1016/j.biortech.2009.10.097

Coolong, T. (2017). Yellow squash and zucchini cultivar evaluation in Georgia. HortTechnology, 27(2), 296-302. https://doi.org/10.21273/HORTTECH03605-16

De Carvalho, G. J., de BastosAndrade, L. A., Gomide, M. B., \& de Figueiredo, P. A. M. (1996). Allelopathic potential of senescent leaves and green leaves and tips of sugarcane, in different concentrations of dry matter, upon the germination of lettuce seeds. Unimar Ciences, 5(2), 19-24.

Drummond, A. R. F., \& Drummond, I. W. (1996). Pyrolysis of sugar cane bagasse in a wire-mesh reactor. Ind. Eng. Chem. Res., 35(4), 1263-1268. https://doi.org/10.1021/ie9503914

Facelli, J. M., \& Pickett, S. T. A. (1991). Plant litter: Its dynamics and effects on plant community structure. Bot. Rev., 57(1), 1-32. https://doi:10.1007/BF02858763

Jhurree-Dussoruth, B., Kallydin, H., \& Bornes, Q. (2011). Investigation into low-cost medium for hardening of in vitro banana plantlets to promote adoption of disease-free plants. Acta Hort., 897, 489-490. https://doi.org/10.17660/ActaHortic.2011.897.69

Kemble, J. M., Sikora, E. J., Patterson, M. G., Zehnder, G. W., \& Bauske, E. (2005). Guide to Commercial Summer Squash Production (ANR-1014). Alabama Cooperative Extension System. Retrieved from http://www.aces.edu/pubs/docs/A/ANR-1014/ANR-1014.pdf 
Kilicaslan, I., Sarac, H. I., Ozdemir, E., \& Ermis, K. (1999). Sugar cane as an alternative energy source for Turkey. Energy Conversion \& Management, 40(1), 1-11. https://doi.org/10.1016/S0196-8904(98)00103-4

Martin, C., Klinke, H. B., \& Thomsen, A. B. (2007). Wet oxidation as a pretreatment method for enhancing the enzymatic convertibility of sugarcane bagasse. Enzyme and Microbial Techn., 40, 426-432. https://doi.org/ 10.1016/j.enzmictec.2006.07.015

Maynard, D. N., \& Hochmuth, G. J. (2007). Knott's handbook for vegetable growers (5th ed.). Wiley, Hoboken, NJ.

Meunchang, S., Panichsakpatana, S., \& Weaver, R. W. (2005). Co-composting of filter cake and bagasse; by-products from a sugar mill. Bioresource Technology, 96, 437-442. https://doi.org/10.1016/j.biortech. 2004.05.024

NeSmith, D. S., \& Hoogenboom, G. (1994). Variation in the onset of flowering of summer squash as a function of days and heat units. J. Amer. Hort. Sci., 119(2), 249-252.

NeSmith, S. D. (1997). Summer squash (Cucurbita pepo L.) leaf number as influenced by thermal time. Sci. Hort., 68, 219-225. https://doi.org/10.1016/S0304-4238(96)00952-1

Nigam, P. (1990). Investigation of some factors important for solid state fermentation of sugar cane bagasse for animal feed production. Enzyme and Microbial Techn., 12, 808-811. https://doi.org/10.1016/0141-0229 (90)90156-K

Pandey, A., Soccol, C. R., Nigam, P., \& Soccol, V. T. (2000). Biotechnological potential of agro-industrial residues. I: sugarcane bagasse. Bioresource Technol., 74(1), 69-80. https://doi.org/10.1016/S0960-8524 (99)00142-X

Peng, F., Ren, J. L., Xu, F., Bian, J., Peng, P., \& Sun, R. C. (2009). Comparative study of hemicelluloses obtained by graded ethanol precipitation from sugarcane bagasse. J. Agric. Food Chem., 57(14), 6305-6317. https://doi.org/10.1021/jf900986b

Rice, E. L. (1984). Allelopathy (2nd ed., p. 422). Acedemic Press, New York.

Rodrigues, R. C. L. B., Felipe, M. G. A., Silva, J. B., Vitolo, M., \& Gómez, P. V. (2001). The influence of pH, temperature and hydrolyzate concentration on the removal of volatile and nonvolatile compounds from sugarcane bagasse hemicellulosic hydrolyzate treated with activated charcoal before or after vacuum evaporation. Brazilian Journal of Chemical Engineering, 18(3), 299-311. https://doi.org/10.1590/S010466322001000300009

Sales, A., \& Lima, S. A. (2010). Use of Brazilian sugarcane bagasse ash in concrete as sand replacement. Waste Management, 30(6), 1114-1122. https://doi.org/10.1016/j.wasman.2010.01.026

Sampietro, D. A., \& Vattuone, M. A. (2006a). Nature of the interference mechanism of sugarcane (Saccharum officinarum L.) straw. Plant Soil, 280, 157-169. https://doi.org/10.1007/s11104-005-2856-5

Sampietro, D. A., \& Vattuone, M. A. (2006b). Sugarcane straw and its phytochemicals as growth regulators of weed and crop plants. Plant Growth Regul., 48, 21-27. https://doi.org/10.1007/s10725-005-5135-9

Sampietro, D. A., Sgariglia, M. A., Soberón, J. R., Quiroga, E. N., \& Vattuone, M. A. (2007). Role of sugarcane straw allelochemicals in the growth suppression of arrowleaf sida. Environmental and Experimental Botany, 60, 495-503. https://doi.org/10.1016/j.envexpbot.2007.02.002

Sampietro, D. A., Vattuone, M. A., \& Isla, M. I. (2005). Plant growth inhibitors isolated from sugarcane (Saccharum officinarum L.) straw. J. Plant Physiol., 163, 837-846. https://doi.org/10.1016/j.jplph. 2005.08.002

Singh, P., Suman, A., \& Shrivastava, K. (2003). Isolation and identification of allelochemicals from sugarcane leaves. Allelopathy J., 12(1), 71-80.

Sun, Y., \& Cheng, J. (2002). Hydrolysis of lignocellulosic materials for ethanol production: A review. Bioresource Technol., 83(1), 1-11. https://doi.org/10.1016/S0960-8524(01)00212-7

Trochoulias, T., Burton, A. J., \& White, E. (1990). The use of bagasse as a potting medium for ornamentals. Scientia Horticulturae, 42(1-2), 161-167. https://doi.org/10.1016/0304-4238(90)90157-A

United States Department of Agriculture, Foreign Agricultural Service. (2017). Sugar: World markets and trade. Retrieved Augurst 14, 2017, from https://apps.fas.usda.gov/psdonline/circulars/Sugar.pdf 
Viator, R. P., Johnson, R. M., Grimm, C. C., \& Richard, E. P. (2006). Allelopathic, autotoxic, and hormetic effects of postharvest sugarcane residue. Agronomy Journal, 98(6), 1526-1531. https://oi.org/10.2134/ agronj2006.0030

Wang, T. S. C., Yang, J., \& Chuang, T. (1967). Soil phenolic acids as plant growth inhibitors. Soil Sci., 103(4), 239-246. https://doi.org/10.1097/00010694-196704000-00003

Xin, L., Kondo, R., \& Sakai, K. (2002). Biodegradation of sugarcane bagasse with marine fungus Phlebia sp. MG-60. J. Wood Sci., 48, 159-162. https://doi.org/10.1007/BF00767294

Yousef, K. M., Salama, M. A., \& Mostafa, A. Z. (2013). Estimation of growing degree days and actual evapotranspiration for squash crop using heat units and neutron scattering method. Journal of American Science, 9(10), 302-307.

\section{Copyrights}

Copyright for this article is retained by the author(s), with first publication rights granted to the journal.

This is an open-access article distributed under the terms and conditions of the Creative Commons Attribution license (http://creativecommons.org/licenses/by/4.0/). 